\section{Storytellers Of Canada/ Conteurs Du Canada}

\section{Jennie Frost}

$\mathrm{O}$ nce upon a time stops clocks, ushers us into a world alive by consent, outlined by words, coloured by listening. Once there, we get involved with the people we meet, and we care what happens to them. When we return to this world, we have memories, ideas, and insights to ponder. Storytelling has magic in it.

Storytelling is one of the world's perennial arts, found in every culture from the earliest times to the present. One of the defining characteristics of human beings is that we attempt to make sense of the world by telling stories about it. Even for us who live in a world so dominated by print and screens, oral stories still function as the major means by which we create our own identity, explain ourselves to others, remember and pass on our personal and family history. All of us tell stories every day.

In 1993, Storytellers of Canada/Conteurs du Canada (SC/CC) was founded to act as the national representative for storytellers across the country. It is dedicated to furthering the art of storytelling and bringing the diverse peoples of Canada together through story. SC/CC is for anybody who is interested in storytelling, for professional and occasional storytellers, and for story listeners. We presently have 146 members, 9 of whom are institutional members.

SC/CC is run entirely by volunteers spread across Canada. We are committed to being a truly national organization. Our main decision-making body is our annual conference, which we hold in a different province every year. Our governing Board aims to have a representative from every province and territory; at the moment all but three are represented. We are striving to be fully bilingual in all our official publications, conference proceedings, and other activities. As of October 2004, we shall have a permanent office in Toronto with a part-time staff member. SC/CC publishes a quarterly newsletter Le raconteur and maintains a website www. sc-cc.com. Members of SC/CC also receive a subscription to Canada's national storytelling journal The Appleseed Quarterly, published by The Storytellers School of Toronto.

In 2000, Storytellers of Canada/Conteurs du Canada became Canada's seventeenth National Arts Service Organization. As gaining storytellers parity with authors in access to government funding through the Canada Council for the Arts Writing and Publishing Program and through the Ontario Council for the Arts. Four storytellers now tour annually as part of the Canadian Children's Book Centre Book Week Tour, and storytellers are now included in the Young Alberta Book Society's annual Chrysalis Festival, which sends storytellers, authors, and illustrators all over Alberta during the month of October each year. For the past three years, SC/CC has provided the jurors who judge the Canada Savings Bonds Story Contest. such, it has been successful in
Every year, SC/CC holds its annual conference in a different province of Canada. A gala four-day event, the conference works on business and policy development in the mornings and devotes the rest of its packed days to professional development and to introducing the conference participants to the stories of the region they are visiting. Nearly half our members attend each year, even though they are largely self-funded. SC/CC members participate in the business and policy-making sessions to a degree I have never witnessed in the many other organizations to which I've belonged. This is a major strength of our organization and reflects our resolve to develop SC/CC in a manner consonant with our art form. Our conferences are celebrations, both of our art and of the close fellowship we have developed over our twelve years' meetings. Next year's conference will be in Calgary, July 20 - 24, 2005. We invite you to come-you do not have to be a member of SC/CC to attend a conference.

Once of SC/CC's most ambitious projects is StorySave. Concerned that the voices and stories of the elders in Canada's storytelling community would be lost-a storyteller is not like an author, whose books outlive him or her $\mathrm{SC} / \mathrm{CC}$ has begun to record Canada's outstanding storytellers. StorySave recordings have been made of Kate Stevens and Joan Bodger. Kate was chosen for her lifetime work with Chinese traditional stories. Joan, one of the founders of the Storytellers School of Toronto, was chosen because of her particular strength in interweaving the traditional and the personal, in finding the mythic in the events of daily life. You can hear stories by both Kate and Joan on the StorySave website (www.storysave.ca) or purchase 
their story CDs from our national office. Work is continuing with Louis Bird, an Omushkego Cree elder who has been collecting the traditional stories of his people for thirty years, and with Jim St. Clair, a man passionate about his Cape Breton heritage, who has listened to, researched, and told Cape Breton stories all his life. Next to be recorded will be Carol McGirr, a notable teller of epic and Icelandic saga, and founder and producer of the Fireside Epic series in Toronto (now in its second decade).

Because many SC/CC members are professional storytellers, we have been working on developing guidelines for storytelling ethics, fee structures, artistic standards, and presenter/performer relationships. These guidelines are available to storytellers across Canada (not just to our members) via our website. We also maintain an online Directory of Storytellers, sorted by province, with information about their backgrounds, repertoires, and preferred age of audiences.

A great many professional storytellers work extensively in schools. At our last two conferences, a policy Working Group began discussion on storytelling in schools. In sharing their experiences in schools, the Schools Group tellers agreed on their deep belief in the educative value of storytelling. Storytelling nourishes oral language, develops human relationships, encourages multicultural learning, celebrates cultural diversity, encourages holistic thinking, and educates the imagination. A visiting professional teller brings a particular artistic, creative, and traditional aspect of storytelling into the classroom, at best an elevated form of the art, which builds on the broad spectrum of storytelling activity already there. In this way the professional extends the exist- ing knowledge of storytelling and creates new possibilities of what can be done. This is particularly true if the storyteller is involved in a residency or other long-term project.

Our Schools Group recommended that SC/CC develop a resource centre for storytellers for information, materials, and reference regarding storytelling in schools. Group leader Jo Kuyvenhoven has offered space at Redeemer College for this collection and is working on a bibliography and resource list. A gifted and experienced teller, Jo is writing a book on storytelling in school. Carol Leigh Wehking and Katherine Grier have volunteered to coordinate a group who will put together a package for storytellers which summarizes or quotes recent research about the value and role of storytelling in education. Christina Pickles has volunteered to run an ongoing column in the SC/CC newsletter Le raconteur to exchange ideas, tips, problem-solving techniques, etc., for storytellers in schools. The Schools Group also hopes to develop

- a template for a contract for schools work which can be downloaded from our website.

- a set of guidelines for schools or other institutions hiring storytellers. The teller would use these to create a document to be sent out with the contract which explains the teller's expectations as to the preparation of the students, preparation of the performance space, management of discipline, and expectation that teachers model good listening for their students.

- a set of guidelines for tellers being hired by a school as to the tellers' responsibilities while in the school.

All this work is still in the preliminary stages. The Schools Group hopes to become a perma- nent policy group at the SC/CC conferences. Certainly they will continue their work at the 2005 conference in Calgary.

For further information about Storytellers of Canada/Conteurs du Canada or the many regional groups with whom we are linked, see the list of contacts below:

- Storytellers of Canada/Conteurs du Canada: \#500A, 720 Bathurst Street, Toronto, Ontario M5S 2R4, phone (416) 588 5234, www.sc-cc.com, email coordinator@sc-cc.com or membership@sc-cc.com

- SC/CC conference information: Mary Hays, Conference Co-Chair storymary@hotmail.com or Karen Gummo, Conference CoChair karengummo@shaw.ca

- StorySave project: www.storysave.ca

- Schools Group leader Jo Kuyvenhoven: jostory@sympatico.ca

- Storytellers School of Toronto: 43 Queen's Park Circle, Toronto, Ontario M5S2C3, phone (416) 656 2445 , www.storytellingtoronto.org, email admin@storytellingtoronto.org

- Victoria Storytellers' Guild: tferris@pacificcoast.net

- Vancouver Society of Storytelling: 1411 Cartwright Street, Vancouver BC V6H3R7, www.vancouverstorytelling.org

- TALES (The Alberta League Encouraging Storytelling) with chapters in Edmonton, Sherwood Park, Parkland, and Calgary: President Pearl-Ann Gooding goodtell@telusplanet.net, Edmonton area contact phone: (780) 433 2932, http://ecn.ab.ca/tales

- Regina Storytelling Circle: Jade Gritzfeld jgritzfeld@sasktel.net

- Stone Soup Stories, Winnipeg: Mary Louise Chown mlchown@shaw.ca 
- Ottawa Storytellers: Ruth Stewart-Verger

ruth_stewart_verger@ocdsb.edu. on.ca

- Stories From the Ages (Ottawa, epic): Jan Andrews

jandrews@magma.ca

- Second Story Workshop \& Storytellers Guild of Baden, Ontario: Mary-Eileen McClear secondstor@golden.net

- Parent - Child Mother Goose Program: Glenna Jantzen gjantzen@web.net
- Montreal Storytelling Guild: Ros Cohen rosebudc@sympatico.ca

- Halifax area: Linda Winham lwinham88@hotmail.com

- Newfoundland: Elinor Benjamin tales@warp.nfld.net

- Yukon International Storytelling Festival: Louise Hardy Louise.Hardy@gov.yk.ca

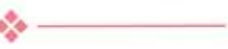

M. Jennie Frost is the National Coordinator of Storytellers of Canada and Treasurer of TALES (The Alberta

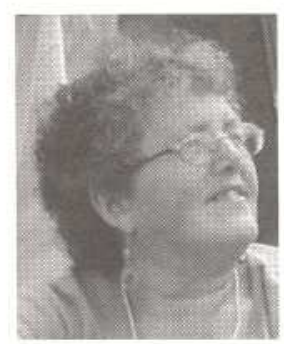

League Encouraging Storytelling). Once a teacher of Latin, she is now a professional storyteller who has performed at festivals, concerts, conferences, libraries and schools in six provinces. She has also published prizewinning poetry and short stories, and has signed a contract to have her first book published, a narrative poem The Courtship of Hippodameia.

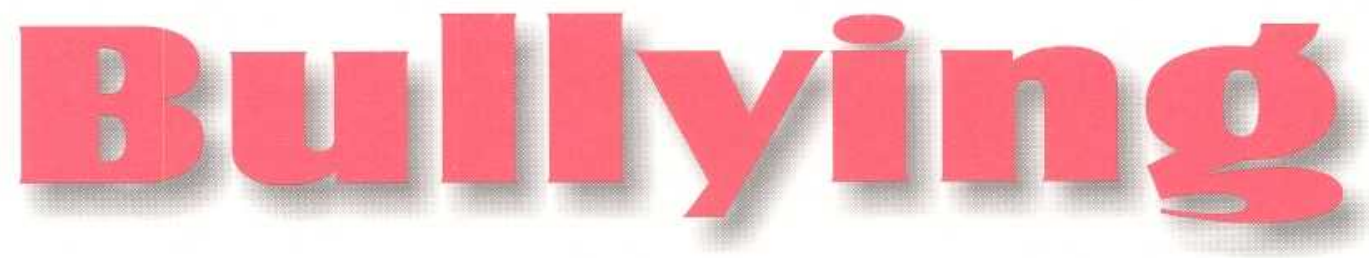

\section{A crisis in our schools and our communities}

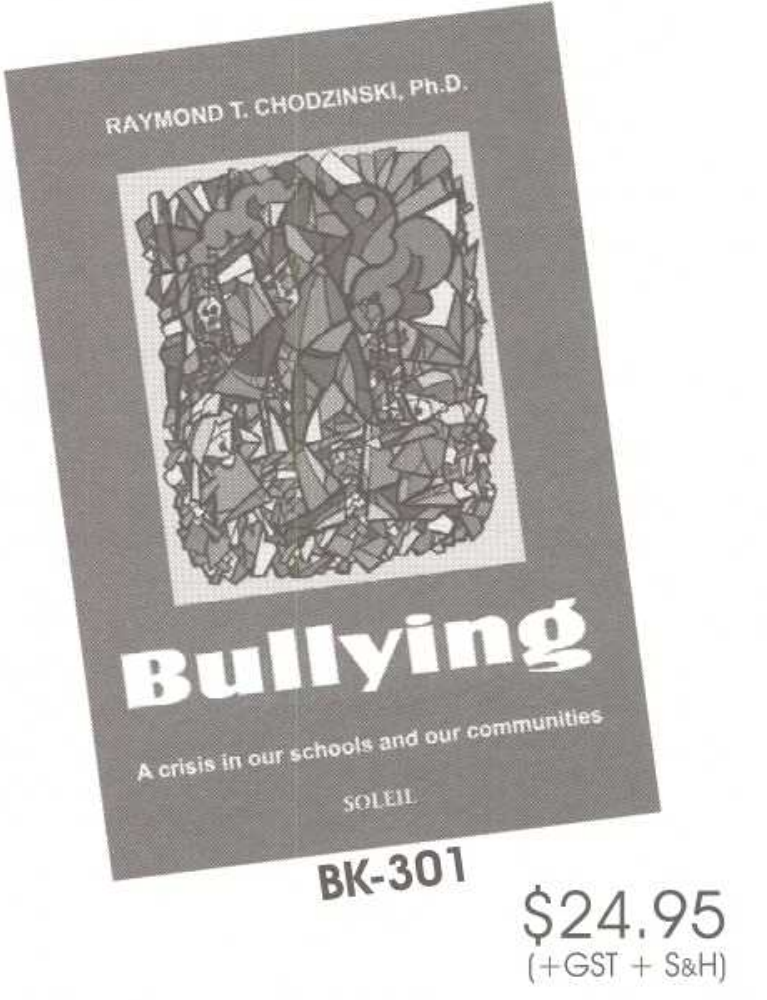

\section{RAYMOND T. CHODZINSKI, Ph.D.}

Dr. Raymond T. Chodzinski earned a Ph.D. at the University of Saskatchewan an M.Ed. at York University and a B.A. at the University of Toronto. His areas of expertise are Counselling and Educational Psychology.

The stories, including my own, and the research, strategies and gleanings contained in this book are a result of reflection on numerous counselling episodes, and many hours spent listening and discussing child-related violence with parents, teachers, social workers, graduate students, conference participants and workshop delegates.

\section{étitions SOLEIL pullisting inc.}

Canada: P.O. Box 847 • Welland, Ontario L3B 5Y5 • Tel. / Fax: (905) 788-2674 soleil@iaw.on.ca 